\title{
Committee Nominates 2017 Officers and Council Members
}

\begin{abstract}
he APSA Nominating Committee met at APSA on February 25, 2017, and has nominated the following candidates for APSA council positions. Each has agreed to serve if elected.

The candidates, along with any additional nominations from the membership, will be put to a vote by the full membership via electronic ballot in July. More information on the new process for electing APSA council members can be found in the newly-approved bylaws at http://apsanet.org/ABOUT/Governing-Documents.

The 2016-2017 nominating committee is Terri Givens, Menlo College (Chair); Christopher Gelpi, Ohio State University; Fred Harris, Columbia University; Tarek Masoud, Harvard University; Jennifer Merolla, University of California, Riverside; Jennifer Pitts, University of Chicago.
\end{abstract}

\section{PRESIDENT-ELECT \\ Rogers M. Smith}

Rogers M. Smith is Christopher H. Browne Distinguished Professor of Political Science at the University of Pennsylvania. His BA is from James Madison College, Michigan State University, and his MA and $\mathrm{PhD}$ degrees are from Harvard University. Trained in the history of political thought and American constitutional law and politics, his scholarship blends empirical and normative concerns focused on the politics of citizenship and identity, especially issues of race, gender, and religion in American constitutional development. He is the author or coauthor of seven books, including Political Peoplehood (2015) and Civic Ideals (1997), which won the APSA's Bunche, Easton, and Greenstone awards. He has authored or coauthored over 90 articles in journals and edited volumes, including the American Political Science Review, Journal of Politics, Studies in American Political Development, and Political Theory. He received the Law and Courts Section's 2004 Wadsworth Award for his APSR article “The 'New Institutionalism' and the Future of Public Law." Smith has supervised $39 \mathrm{PhD}$ theses and received Penn's Provost Award for Distinguished PhD Mentoring; Lindback Award for Distinguished Teaching; Dean's Award for Mentoring Undergraduate Research; and a Distinguished Undergraduate Teaching Prize from Yale, where he taught from 1980 to 2001.

At Penn he served as department chair from 2003 to 2006 and is now associate dean for social sciences. He founded the Penn
Program on Democracy, Citizenship, and Constitutionalism in 2006 and has since directed it. He also cofounded the Teachers Institute of Philadelphia, a university-public school partnership. His APSA roles include chair of the Politics and History Organized Section, 2001-2002; program chair of Constitutional Law and Jurisprudence, 2001-2002; cochair of the Task Force on Graduate Education, 2002-2003; member of the Committee on the Status of Blacks in the Profession, 2004-2007; Council Member, 2005-2006; chair of the Perspectives on Politics editor search committee, 2008; Vice President, 2008-2009; member of the Task Force on Public Engagement, 2013-2014; and cochair of the Migration and Citizenship Section, 2013-2015. He received the Frank J. Goodnow Award in 2010. He is a Fellow of the American Academy of Arts and Sciences, the American Academy of Political and Social Science, and the American Philosophical Society.

Statement of Views: I have long championed a discipline that uses plural methods to address major pressing and enduring political questions. I hope to promote an association that is broadly inclusive and responsive and a profession that aids in the flourishing of all research that advances these ends; that strengthens teaching; and that fights in the public sphere to protect and improve higher education in an era of declining support for honest, innovative scholarship and pedagogy.

\section{VICE PRESIDENTS}

\section{Evelyne Huber}

Evelyne Huber is Morehead Alumni Professor of Political Science and chair of the department of political science at the University of North Carolina, Chapel Hill. She studied at the University of Zurich and received both her MA and $\mathrm{PhD}$ from Yale University. She studies democratization and redistribution in Latin America

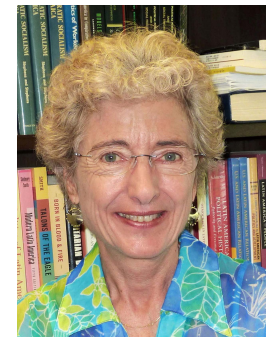

and advanced industrial democracies. She is the author of The Politics of Workers'Participation: The Peruvian Approach in Comparative Perspective (1980); Democratic Socialism in Jamaica (with John D. Stephens, 1986); Capitalist Development and Democracy (with Dietrich Rueschemeyer and John D. Stephens, 1992); Development and Crisis of the Welfare State (with John D. Stephens, 2001); and Democracy and the Left: Social Policy and Inequality in Latin America (with John D. Stephens, 2012). The last three books were co-winner of the Outstanding Book Award 1991-1992 from the ASA Political Sociology Section, winner of the Best Book Award 2001 from the APSA Political Economy Section, and winner of the Outstanding Book Awards 2013 from the ASA Sociology of Development Section and the Political Economy of the World System Organized Section. She has also contributed articles to, among others, World Politics, Latin American Research Review, Comparative Politics, Politics and Society, Comparative Political Studies, The Journal of Politics, American Journal of Sociology, American Sociological Review, and Economic Perspectives. She was a member of the Institute for Advanced Study at Princeton University, a fellow at the Wilson Center, the Swedish Collegium for Advanced Study, the Kellogg Institute, the Hanse-Wissenschaftskolleg, and the Collegio Carlo Alberto, and she received an Honorary Doctorate in the Social Sciences from the University of Bern in 2010, a Guggenheim Fellowship in 2010, and the Distinguished Teaching Award for Post-Baccalaureate Instruction from the University of North Carolina in 2004. 
She is a former President (2012-2013) of the Latin American Studies Association and she served on the APSA Council from 2010 to 2012.

Statement of Views: The APSA has many functions, key among them to provide professional services to individual members and departments and to project the public face of political science. To perform the membership functions successfully, members of the APSA leadership need to be aware of and responsive to the diverse needs of the membership. To be successful in the public presentation of our profession they have to be able to articulate what political science can contribute to the solution of the major challenges facing our communities, the country, and the world. I am strongly committed to working for success in both areas.

\section{Pippa Norris}

Pippa Norris is a comparative political scientist who has taught at Harvard University for a quarter century. She is Laureate

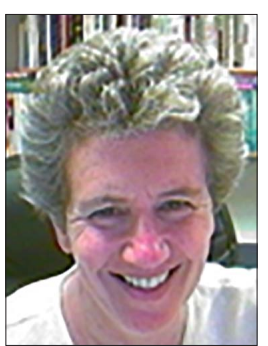
Fellow and Professor of Government and International Relations at the University of Sydney, the Paul McGuire Lecturer in Comparative Politics at the John F. Kennedy School of Government, Harvard University, and director of the Electoral Integrity project.

Honors include Pennsylvania State University's 2016 Brown Medal for Democracy; the APSA 2016 Academic Leadership in Political Science; IPSA's 2014 Karl Deutsch award, the 2011 Johan Skytte prize in political science, with Ronald Inglehart; the ARC's 2011 Kathleen Fitzpatrick Australian Laureate Fellowship, a special recognition award by the UK Political Science Association; and Doctor honoris causa by the University of Edinburgh and Warwick University. Book awards include the 2006 Doris A. Graber award for the best book in political communications (for A Virtuous Circle) and the Virginia Hodgkinson prize from the Independent Sector (for Sacred and Secular).

Her research compares public opinion and elections, democratic institutions and cultures, gender politics, and political communications in many countries worldwide. She is founding director of www.electoralintegrityproject.com, established in 2012, and supported by the Australian Research Council and other funding agencies. Before Harvard, she taught at Edinburgh University and she studied at Warwick University and the LSE.

A well-known public speaker and author, she has published almost fifty books. In 2017, this includes Strengthening Electoral Integrity, Why American Elections are Flawed, and Election Watchdogs. Her current research focuses on a new book on populism. In professional service, she has been elected to executive councils for APSA, IPSA, the PSA-UK, and the World Values Survey Association. Within APSA, she has served on many committees and been president of research sections on Women and Politics Research, Political Communications, and Elections, Public Opinion, and Voting Behavior, as well as on the executive of the British Politics Group and the Representation and Elections Section. For details, see www.pippanorris.com and @PippaN15.

Statement of Views: If elected, I would seek to advance the professional values of diversity, engagement, relevance, cosmopolitanism, participation, pluralism, and rigor. In particular, I believe that political science is at its best when it is theoretically driven, methodologically sound, and policy-relevant to real world problems. For the latter, I would strive to strengthen ties and build bridges between the work of the association and the world of practitioners and agencies seeking to strengthen democratic governance in the international community.

\section{Gary M. Segura}

Gary M. Segura is dean of the Luskin School of Public Affairs at University of California, Los Angeles. His work focuses on issues of political representation and social cleav-

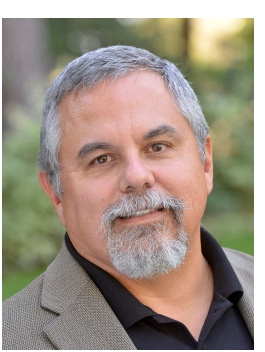
ages, the domestic politics of wartime public opinion, and the politics of America's growing Latino minority. Among his most recent publications are Latino America: How America's Most Dynamic Population is Poised to Transform the Politics of the Nation with Matt Barreto (2014) and two books with the Latino National Survey team. Earlier work has been published in the American Political Science Review, American Journal of Political Science, and the Journal of Politics, among many others. Over the last 18 years, he has directed polling research that has completed over 100,000 interviews of Americans of all backgrounds on matters of political importance. He has briefed legislators and senior administration officials and appeared on numerous news media outlets. Segura served as an expert witness on the nature of political power in all three of landmark LGBT marriage rights cases in 2013 and 2015, Windsor v. United States, Hollingsworth v Perry, and the historic Obergefell v. Hodges. Segura was one of the principal investigators of the 2012 and 2016 American National Election Studies, and was one of the principal investigators of the Latino National Survey, in 2006. He is a past president of the Midwest Political Science Association and the Western Political Science Association, and a past executive council member of the American Political Science Association. $\mathrm{He}$ is a past president of El Sector Latino de la Ciencia Política (Latino Caucus in Political Science). In 2010, he was elected a Fellow of the American Academy of Arts and Sciences.

Statement of Views: The discipline of political science faces a number of challenges, two of which attract my focus. First, we increasingly confront an environment of public discourse that denigrates actual knowledge in favor of invective. I support existing efforts by the association, and by many of its members, to aggressively engage the public with the findings and implications of our work. In the "post-truth" or "postfact" environment, our response should be to redouble our efforts toward scientifically sound policy making and working to encourage new and innovative paths to dissemination. Second, the widening gap between the demographic composition of political science professionals and the society we claim to serve is narrowing our ability to identify and address important social and political problems. We must work to identify new and different ways to advance the inclusiveness of the discipline and association and honestly confront the practices and policies that thwart those efforts. I look forward to advancing the interests of the Association and discipline should I be fortunate enough to serve.

\section{TREASURER}

\section{Thomas Pepinsky}

Thomas Pepinsky is associate professor and director of undergraduate studies in the department of government at Cornell University. He specializes in comparative politics

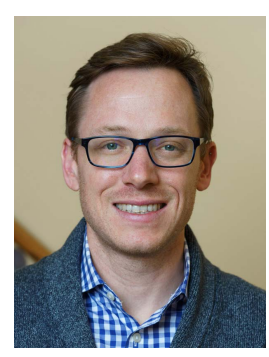


and international political economy, with a focus on emerging markets and Southeast Asia. He is the author of Economic Crises and the Breakdown of Authoritarian Regimes: Indonesia and Malaysia in Comparative Perspective (2009) and coauthor of Piety and Public Opinion: Understanding Indonesian Islam (forthcoming), as well as articles appearing or forthcoming in the American Journal of Political Science, British Journal of Political Science, Journal of Politics, Perspectives on Politics, Comparative Political Studies, World Development, World Politics, and other journals. His past work has been recognized with awards such as the Franklin L. Burdette/Pi Sigma Alpha Award for Best Paper presented at the 2009 APSA annual meeting. He received his $\mathrm{PhD}$ from Yale University in 2007.

Pepinsky has been active in APSA, serving as co-organizer of the Comparative Politics Organized Section for the 2017 Annual Meeting and organizer of the Political Economy Organized Section for the 2013 Annual Meeting. He also serves as a member of the steering committee for the Association for Analytical Learning on Islam and Muslim Societies (aalims.org), and is the founding president of the American Institute for Indonesian Studies and cofounder of the Southeast Asian Research Group (seareg. org). He regularly teaches courses in comparative politics, political economy, Southeast Asian politics, and research methods.

Statement of Views: In a time of great political uncertainty, APSA should play a leading role in demonstrating the value and purpose of political science. This means standing proudly for freedom of inquiry, defending critical scholarship regardless of its methods or conclusions, and supporting engaged and policy-relevant research on substantively meaningful topics. I believe that APSA can play a constructive role in public life, highlighting the links from teaching and scholarship to citizenship and service, and that this is particularly urgent when much of the public expresses skepticism towards both politics and science. I am further committed to an APSA that does not just represent the diversity of its membership, but strives to further reach out to those scholars and teachers who have been historically underrepresented in our discipline, in the United States, and abroad.

\section{COUNCIL}

\section{Joseph Carens}

Joseph H. Carens is professor of political science at the University of Toronto and

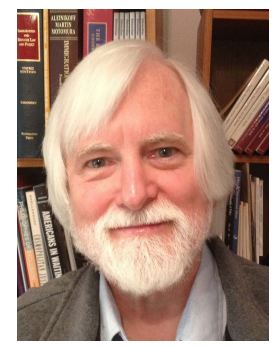

professorial fellow at the Institute for Social Justice at Australian Catholic University in Sydney. He holds a PhD and an MPhil in political science from Yale University as well as an MPhil in religious studies from Yale and an $\mathrm{AB}$ summa cum laude from the College of the Holy Cross. He is a Fellow of the Royal Society of Canada.

Carens is a normative political theorist who works on questions about immigration, multiculturalism, and economic justice. He has written four books, coedited two others, and published over 90 articles and book chapters. His most recent book The Ethics of Immigration (2013) won five book awards, including the David Easton award from the Foundations of Political Theory Organized Section of the APSA and the C. B. Macpherson award from the Canadian Political Science Association. An earlier book Culture, Citizenship, and Community: A Contextual Exploration of Justice as Evenhandedness (2000) also won the Macpherson award. He is currently working on a project titled "Taming the Market," whose goal is to find ways to separate the organizational virtues of the market from its distributional and other defects.

Within the APSA, in addition to presenting papers at over 20 of the annual meetings, Carens has served as chair of the Franklin L. Burdette/Pi Sigma Alpha Award Committee, as cochair of the program committee for the Division on Migration and Citizenship, as a member of the David Easton Book Prize Committee, and as a member of the committee to choose a new editorial team for Perspectives on Politics in 2016.

Statement of Views: I strongly support efforts to promote diversity of various kinds within APSA, including (but not only) methodological pluralism. I would also like to try to promote more conversations between scholars in political theory and scholars in other subfields. Finally, for many political scientists, the Annual Meeting is their most important connection to APSA. I worry that many members do not understand what principles govern the organization of the Annual Meeting with respect to such matters as the number of papers assigned to particular divisions, the principles that affect acceptance or rejection of proposals, the way rooms and time slots are assigned, and so on. Many people may not care about such issues, but
I would like the Association to provide as much information as possible to those who do and to find ways to be open to feedback from members about possible improvements.

\section{Lisa García Bedolla}

Lisa García Bedolla is Chancellor's Professor at the University of California, Berkeley. She received her $\mathrm{PhD}$ in political science from Yale University. García Bedolla studies

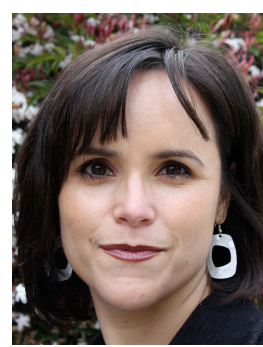
why people choose to engage politically, and she has used a variety of social science methodsparticipant observation, in-depth interviewing, survey research, field experiments, and geographic information system (GIS) - to shed light on this question. She uses the tools of social science to explore the causes of political inequalities in the United States, considering differences across the lines of ethnorace, gender, class, geography, sexuality, et cetera. García Bedolla believes an intersectional approach is critical to recognizing the complexity of contemporary US politics. She has consulted for campaigns, ballot initiatives, and national funders and has partnered with over a dozen community organizations working to mobilize lowincome communities of color.

She is author or coauthor of three awardwinning books and over thirty articles and book chapters exploring these questions, earning five national book awards and other awards. Her books include, with Melissa Michelson, Mobilizing Inclusion (2012), Latino Politics, second edition (2014), and Fluid Borders (2005). She is the only person ever to have won APSA's Ralph Bunche Award twice.

Over the course of her career, she has been very active within APSA, serving on the Nominating Committee, as cochair of the Committee on the Status of Latinas y Latinos in the Profession, as a member of two APSA Presidential Task Forces, as copresident of the Women and Politics Research Organized Section, as program chair for the Women and Politics and Race, Ethnicity, and Politics (REP) Organized Sections, on the executive committees of the REP and Public Policy sections, and on six award committees.

Statement of Views: I believe that APSA plays an important role in fostering a vibrant and inclusive intellectual community within political science. I am interested in serving on the APSA Council in order to help the 
association find ways to deepen and enhance that community, making it more welcoming of scholars from different types of institutions, who engage in research from diverse epistemological and methodological vantage points, and who come from different backgrounds. It is important that members of the Council be mindful of the power dynamics within our profession and work to craft policies that address the needs of the many constituencies that make up the association.

\section{Lilly J. Goren}

Lilly J. Goren is professor of political science and global studies at Carroll University in Waukesha, Wisconsin, where she received the 2011 Benjamin F. Richason, Jr. Faculty

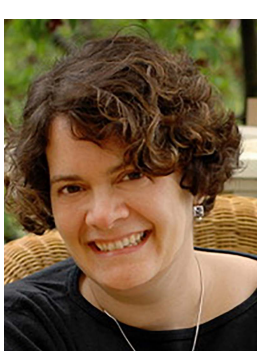

Award in teaching, research, and educational innovation. She holds an MA and PhD from Boston College.

Her areas of expertise include American politics, popular culture and politics, women's and gender studies, and politics and literature. She is coauthor, with Linda Beail, of Mad Men and Politics: Nostalgia and the Remaking of Modern America (2015). She is coauthor, with Justin Vaughn, of Women and the White House: Gender, Popular Culture, and Presidential Politics (2012), winner of both the Popular Culture Association/American Culture Association's 2014 Susan Koppelman Book Award, and the Southwest Popular Culture Association's 2014 Peter C. Rollins Book Award. Goren edited You've Come a Long Way, Baby: Women, Politics, and Popular Culture (2009). She is author of Not in My District: The Politics of Military Base Closures (2003), and coauthor of The Comparative Politics of Military Base Closures (2002). Goren has published articles in a variety of journals.

Goren has twice served as chair of the Politics, Literature, and Film Organized Section, where she is currently a member-atlarge, and she is also serving a second term on the executive board of the Presidents and Executive Politics (PEP) Organized Section. Service to the APSA also includes membership on the Okin-Young Award Committee and on a variety of awards committees for the PEP and Politics, Literature, and Film Organized Sections. Goren was elected to a three-year term on the Governing Committee of the Association for Political Theory (APT), where she served as conference committee cochair for the annual meeting in 2015.
She will be a Fulbright Fellow at the University of Bonn in the spring of 2018.

Statement of Views: I have long advocated for APSA's attention to faculty (and thus students) at all kinds of colleges and universities. The role of APSA should be to engage and support scholars and teachers, including supporting public scholarship, civic engagement, collaborative, interdisciplinary, and multidisciplinary approaches to teaching, publishing, and work in political science.

APSA needs to continue to integrate and reflect a diversity of views and experiences from the membership, which means paying particular attention to underrepresented groups within the organization, especially individuals of color, women, religious and ethnic minorities, and LGBTQ members.

\section{Simon Jackman}

Simon Jackman (PhD 1995 Rochester) is professor of political science and CEO of the United States Studies Centre, University of Sydney in Australia. From 1996 to 2016

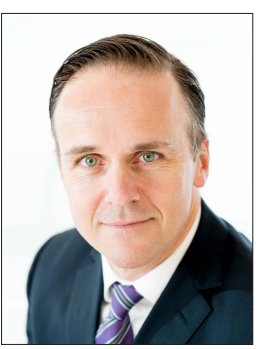
he taught at Stanford University's department of political science, with a courtesy appointment in statistics; prior to Stanford University, he held appointments at the University of Chicago and Australian National University. In 2013 Jackman was elected to the American Academy of Arts and Sciences. He is a past president and Fellow of the Society for Political Methodology. From 2009 to 2016 he was one of the principal investigators of the American National Election Studies. He is the author of Bayesian Analysis for the Social Sciences (2009) and many refereed articles on political behavior, political methodology, and political institutions.

Statement of views: Three related priorities underlie my candidacy for APSA Council. First, our profession and the association can and should respond to the "populist turn" in the United States and in other democracies where APSA members work and live. The profession, the association, and its Council must demonstrate our commitment to a science of politics and government, not merely as a scholastic endeavor, but as an institution of democracy itself, highlighting the value of social science not just to policy makers or political practitioners, but to civil society more generally.
Second, the association's considerable resources-its finances, its members-should continue to be aggressively deployed to support future generations of scholars. These efforts include helping younger members of the profession find research funding, especially as we enter a period in which the already tight Federal funding environment is likely to become even less generous for social scientists. Can the association's support of refereed journals be improved to create additional opportunities? Can the Association per se-not individual scholars, their universities, or organized sections-take a larger role in developing novel approaches to communicating our research and teaching to key audiences, including a lay public?

Third, there have always been many political scientists working away from universities: in and around government and at think tanks and other nonprofits, but increasingly in forprofit research enterprises (survey research, political and policy consulting) and the tech sector. The association and its members could benefit tremendously from deeper and more meaningful engagement with these "applied" political scientists, not only as a tangible demonstration of the value and relevance of our teaching, but also as potential research partners.

\section{Matthew Kocher}

Matthew Kocher, PhD University of Chicago, 2004, has been a lecturer in the political science department and the Jackson Institute at Yale University since 2007 . He will

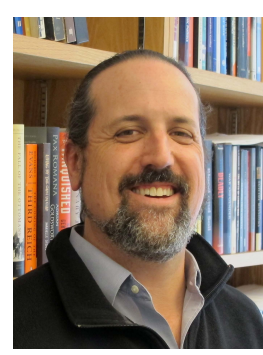
join the faculty of the political science department and the School of Advanced International Studies (SAIS) at Johns Hopkins University as a senior lecturer in 2017. Kocher's research is concerned with the causes and internal dynamics of civil wars and other violent social processes. Within this field, he has been an innovator in the use of geographical information systems (GIS), quantitative micro-comparative analysis, and the construction of datasets from archival materials. His work has been published in the American Journal of Political Science, World Politics, Perspectives on Politics, Politics and Society, the Journal of Peace Research, Political Analysis, and Política y Gobierno. He has won the 2006 Gabriel A. Almond Award for the best dissertation in comparative politics, the APSA Comparative Politics Section's 2009 Gregory 
Luebbert award for the best professional article in comparative politics, and the 2009 Article of the Year Award from the Journal of Peace Research. Kocher has previously taught at the Centro de Investigación y Docencia Económicas (CIDE) in Mexico City, the University of Notre Dame, and the University of Chicago.

Statement of Views: I am honored to be nominated to the APSA Council. Like most instructors in the discipline of political science, I have spent the majority of my career in higher education in a non-tenure track position. My principal objective on the Council will be to attempt to represent the interests of contingent faculty within the association. As a researcher, my work has spanned methodological divides. On the Council, I will advocate for a pluralistic discipline that continues to recognize and promote methodological and theoretical diversity.

\section{Erin Richards}

Erin Richards is senior I tenured faculty at Cascadia College in Bothell, Washington. Her academic interests include American institutions, state and local government, women in politics, citizenship, and pedagogy. She has published on community college teaching and worked on a multiyear multi-campus project examining learning and civic engagement in

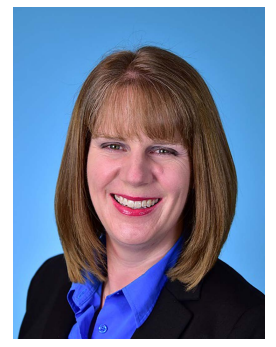

American government courses. She also helped create and implement curriculum for the bachelors of applied science in sustainable practices degree at Cascadia College.

Richards has served the discipline in many capacities including chairing the Ad Hoc Committee on the Status of Community Colleges in the Profession for APSA, the report of which led to creation of the Committee on the Status of Community Colleges in the Profession on which she serves. She also currently serves on the editorial board for the Journal of Political Science Education. Richards has also served as executive committee member, secretary, president-elect, president, and ex-officio for the Pacific Northwest Political Science Association, as well as on the Executive Committee for the Political Science Education Organized Section of APSA. Finally, Richards served on the Program Committee for APSA's Teaching and Learning Conference, where she helped create a community colleges track which led to increased community college faculty attendance at the conference.

Statement of Views: As a member of the Council, I look forward to suggesting, advocating for, and supporting programs and policies that further APSA's core objective of "promoting high quality teaching and education about politics and government." Community college faculty specifically, and faculty primarily focused on teaching generally, have identified professional development and networking opportunities they desire to help them be both better teachers and better political scientists. I hope to serve as a voice of this population to help identify and address these needs; I hope that increasing focus on teaching will also help to increase membership in APSA as more teaching focused faculty see value in membership in the organization. Finally, I believe my presence on the Council will be a tangible sign that APSA values community colleges and their faculty as legitimate members of the discipline addressing a concern noted by the Ad Hoc Committee for the Status of Community Colleges in the Profession. I look forward to working with APSA staff and fellow Council members to ensure that APSA is positioned to direct resources to programs and policies that ensure political science faculty continue to engage in best practices to educate future citizens.

\section{Valeria Sinclair-Chapman}

Valeria Sinclair-Chapman is associate professor of political science and College of Liberal Arts University Scholar at Purdue University. She is director of the Cen-

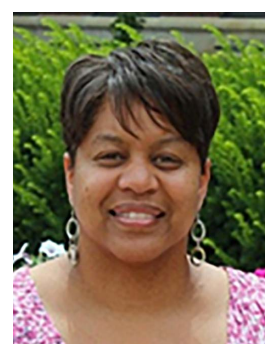
ter for Research on Diversity and Inclusion and facilitator for the ADVANCEPurdue Diversity Catalyst Program, an NSF-funded project to increase the numbers of women of color and women more generally in STEM fields at Purdue. Sinclair-Chapman is author, with Fredrick Harris and Brian D. Mc Kenzie, of Countervailing Forces in African-American Political Activism, 1973-1994 (2006), winner of the 2007 Ralph Bunche Book Award presented by the American Political Science Association and the 2007 W. E. B. DuBois Book Award presented by the National Conference of Black Political Scientists. She is author or coauthor of several book chapters, as well as articles in Legislative Studies Quarterly, Journal of Politics, Electoral Studies, Political Research Quarterly, PS: Political Science \& Politics, and Politics, Groups, and Identities. Sinclair-Chapman is a former Ford Fellow, as well as a recipient of the Women's Research and Education (WREI) Congressional Fellowship. She has demonstrated a commitment to diversity and inclusion in higher education and has received multiple awards for contributions to student life.

Sinclair-Chapman is an active member of the American Political Science Association, the National Conference of Black Political Scientists, the Midwest Political Science Association, the Western Political Science Association, and the Southern Political Science Association. She is former copresident of APSA's Race, Ethnicity, and Politics Organized Section, a member of APSA's Committee on the Status of Blacks in the Profession, and past president of SPSA's Women's Caucus of the South. She has served on the council of the National Conference of Black Political Scientists and currently serves on the council of the Midwest Political Science Association. She has served on numerous award committees, including the Leon Weaver Award for APSA's Electoral Systems Section, MPSA's Lucius Barker Award, and as chair of NCOBPS's DuBois Book Award committee. In January 2016, Sinclair-Chapman was named colead editor of Politics, Groups, and Identities, a journal of the Western Political Science Association.

Statement of Views: The American Political Science Association is the premiere association of political scientists worldwide. As a member of the Council, I will work to ensure that the association lives up to its promise and responsibility to advance the scholarship and careers of members across the discipline in diverse institutions, from diverse backgrounds, and with diverse methodological approaches.

\section{Laura Sjoberg}

Laura Sjoberg is Colonel Allen R. and Margaret S. Crow Term Associate Professor of Political Science at the University of Florida. She received her BA from the University of Chicago, her $\mathrm{PhD}$ from the University of Southern California, and her JD from Boston College. Her research centers around gender,

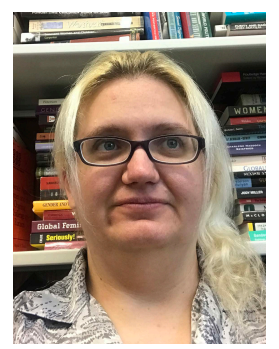


sexuality, and security in global politics, with foci on feminist security theorizing and women's violence in global politics. She is the author or editor of twelve books, including, most recently, Women as Wartime Rapists (2016) and (with J. Samuel Barkin) Interpretive Quantification (2017). Her work has been published in more than two dozen journals in political science, international relations, gender studies, law, and geography, including International Studies Quarterly, Feminist Review, and Political Geography. She currently serves as Homebase Editor of the International Feminist Journal of Politics and coeditor of International Studies Review. She teaches undergraduate and graduate courses in methodology, international security, international law, and gender in global politics.

Sjoberg served as program chair of the Sexuality and Politics Organized Section from 2012 to 2013 and section chair from 2013 to 2014. She served as the co-program chair of the Women and Politics Organized Section from 2013 to 2014, and secretary of the section from 2010 to 2012. She participates in the APSA mentoring program, and served on the Committee to Rename the International Relations Dissertation Award from 2015 to 2016. In addition to her work at APSA, she has been active in the International Studies Association (where she served as vice president from 2015 to 2016), the Southern Political Science Association, the International Studies Association-Northeast, and the International Studies Association-West. She has served on the editorial boards of International Studies Quarterly, International Studies Perspectives, Review of International Studies, Foreign Policy Analysis, Critical Studies on Terrorism, and the Journal of Global Security Studies.

Statement of Views: I appreciate the honor of nomination to the APSA Council. I have been a member of and benefitted from
APSA for my entire career, and I look forward to having the opportunity to give back. It is important to me that APSA serves its diverse membership. This means, to me, paying attention to how APSA serves its minority members, how it serves its members from a wide variety of institutions, and how it serves its members of a wide variety of scholarly interests. Only through valuing representational and substantive diversity in our governance and in our programming will APSA enrich both teaching and research. I look forward to working to push APSA even further as it develops programming to promote diversification.

\section{Carol Weissert}

Carol Weissert (nominated for one-year term) is LeRoy Collins Eminent Scholar and Professor of Political Science at Florida State University (FSU). In 2016 she was

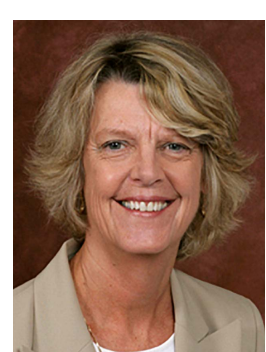
Fulbright Distinguished Professor in American Political Science at Flinders University in Adelaide, Australia.

Her principal research interests are federalism and state politics with a special focus on health policy. She is the former editor of Publius: The Journal of Federalism. Her current research explores intergovernmental bargaining between federal and state governments, vertical diffusion of policies, policy implementation, and the impact of devolution.

She is coauthor of Governing Health: The Politics of Health Policy (now in its fourth edition); her research has appeared in journals including the Journal of Politics, Publius: The Journal of Federalism, Journal of Health Politics, Policy and Law, Legislative Studies Quarterly, Journal of Public Administration
Research, and Theory, Health Affairs, Political Research Quarterly, and Administration and Society.

She is the recipient of the Daniel Elazar Award for Distinguished Scholarship in Federalism and Intergovernmental Relations from the Federalism Organized Section of APSA and the Donald Stone Award for Distinguished Scholarship in Intergovernmental Relations from the Organized Section on Intergovernmental Relations of the American Society of Public Administration. She is a fellow of the National Academy of Public Administration.

She has been president of the Southern Political Science Association and has chaired the Federalism Organized Section of APSA. In addition, she has held leadership positions in and chaired committees for State Politics and Policy, Public Policy, and Health Politics and Policy Organized Sections of APSA. She was chair of APSA's Organized Section Committee.

She has served on editorial boards of the American Political Science Review, State Politics and Policy Quarterly, Publius: The Journal of Federalism, and the Journal of Political Science Education. At FSU she is director of the LeRoy Collins Institute for Public Policy. Prior to coming to FSU, she was professor of political science and director of the Institute for Public Policy and Social Research at Michigan State University. Her PhD in political science is from the University of North Carolina, Chapel Hill.

Statement of Views: On the Council, I will encourage cooperation and close working relationships with organized sections which comprise a key component of the success of APSA. I will work to strengthen APSA's efforts to welcome and mentor new members, especially graduate students and junior scholars, and to foster new mechanisms for member feedback on APSA's member services and support.

\section{Continuing Council Members}

\section{PRESIDENT}

\section{Kathleen Thelen}

Kathleen Thelen is Ford Professor of Political Science at MIT. She received her BA from the University of Kansas and her PhD from the University of California, Berkeley. Thelen is a comparativist whose work focuses on the origins and evolution of political-economic institutions in the rich democracies. Her latest book, Varieties of Liberalization and the New Politics of Social Solidarity (2014), received the Barrington Moore Prize and was cowinner of Best Book

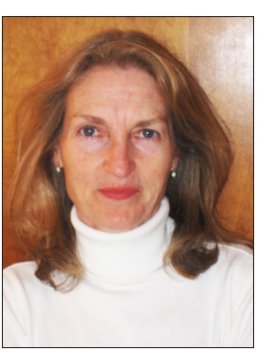

in the European Politics and Society Section. A previous work, How Institutions Evolve, was selected for the 2006 Mattei Dogan Award, and shared the 2005 Woodrow Wilson Foundation Award. Thelen has also contributed to the literature on institutional analysis, including Advances in Comparative Historical Analysis (2015) and Explaining InstitutionalChange (2010), both 